\title{
Detection of maternal immunity of enterotoxaemia vaccine of Clostridium perfringens type $A$ in serum of pregnant dams and offspring of rabbit
}

\author{
Enany, M. E. ; Abdalla, Y. A ** and Reham, M. Wahid*** \\ Faculty of veterinary medicine, Suez Canal University" \\ Veterinary Serum and Vaccines Research Institute, Abbassia, Cairo**
}

\begin{abstract}
The rabbit Clostridial enterotoxaemia bloat vaccine has been produced for the first time in Egypt at Anaerobic Department at Veterinary Serum and Vaccines Research Institute .It was found that this vaccine induced efficient immunity when it was injected in two doses (4 weeks interval) as $2 \mathrm{ml}$ for adult rabbits and $1 \mathrm{ml}$ for offspring as the results of vaccinated rabbit at breeding period was $1 \mathrm{IU} / \mathrm{ml}, 3 \mathrm{IU} / \mathrm{ml}$, and $1.63 \mathrm{IU} / \mathrm{ml}$ by mouse neutralization test, heamolytic inhibition assay, and ELISA respectively. Also it produced a very good protection against the disease for 5 months, so animal could be revaccinated after 5 months from primary vaccination. Also during pregnancy booster dose should be given to increase the maternal antibodies titer against the disease, the results of pregnant dams post booster vaccination were $3 \mathrm{IU} / \mathrm{ml}$, $7 \mathrm{IU} / \mathrm{ml}$, and $3.74 \mathrm{IU} / \mathrm{ml}$ which give passive immunity to the newborn till 4 - 6weeks after birth, the titer was $0.5 \mathrm{IU}, 1 \mathrm{IU} / \mathrm{ml}$, and $1.17 \mathrm{IU} / \mathrm{ml}$ one month post parturition.
\end{abstract}

\section{Introduction}

Rabbit industry is one of the small live stock industries that play a considerable role in solving the problems of meat shortage in developing countries (Lepas et al,1977).

Enteritis in rabbit mainly after weaning is the major cause of economic commercial rabbitaries as it induces sudden death and high mortalities about $27-50 \%$ at five to seven weeks of age (Wcharmann and wolff, 1985). Many causes losses in are claimed in induction of enteritis in rabbit as Clostridium spp., Escherichia coli, staphylococcus aureus, salmonella spp. and Vibrio spp. (Hara- Kudo et al, 1996). Clostridium spp. are the most important one (Szemeredi et al, 1983) as they adversely affecting rabbit's industry all over the world (Diab et al., 2003).

Enterotoxaemia in rabbits is a multifactorial disease associated with changes in the immature caecum at weaning (Lelkes, 1987). Investigations were conducted on enterotoxaemia outbreaks in 
different rabbit farms in Egypt and Clostridium perfringens type A isolated from the caecum of rabbits which died suddenly after short illness with severe diarrhea. Also the alpha toxin of $\boldsymbol{C}$. perfringens type A could be detected in the filtrate of caecal contents of died rabbits (Diab et al, 2003).

A vaccine was produced from a locally isolated toxigenic strains of C.perfringens type $\mathrm{A}$ and was successfully used in many rabbit farms resulting in control of the disease in vaccinated farms (Diab et al, 2003). The vaccine was prepared for the first time in Egypt in the Anaerobic Department, Veterinary Serum and Vaccine Research Institute under the name of "Rabbit Clostridial enterotoxaemia bloat vaccine". Vaccine give active immunity in older rabbits and passive immunity to the newborns via maternal antibodies and colostrums (Smith and Holdman, 1968; Djurickovic,et al;1975; Itodo, 1991).

Maternal immunization has been used successfully in poultry with certain infectious agent $\mathrm{s}$ such as infectious bursal disease virus (Sharma,1999). A maternal immunization strategy for poultry is an attractive approach for the control of necrotic enteritis, due to the potential of protecting high numbers of progeny from each vaccinated bird (Lovland et al, 2004).

So, the aim of this work is to reach the highest immune response level in Dam's at pregnancy, parturition till reaching to offspring.Following up the maternal immunity in offspring and determine the best time for revaccination.

\section{Materials \& Methods}

Rabbit enterotoxaemia and Bloat Vaccine was supplemented from Anaerobic Vaccine Research Department, Veterinary Serum and Vaccine Research Institute.

Breeding dams: Twenty female bosket rabbit were vaccinated at breeding period, each one received two doses of $2 \mathrm{ml} \mathrm{S} / \mathrm{C}$ at three weeks interval then blood samples were collected after two weeks from second dose. Breeding dams were undergone to pregnancy and boostered by one dose of $2 \mathrm{ml} \mathrm{S} / \mathrm{C}$ then blood samples were collected after two week and before parturition. After parturition, blood samples collected at different times (after 48h, 2 week and one month). Collected serum samples from dams during breeding and pregnancy were undergone for antitoxin units determination using (mouse serum neutralization test, ELISA and haemolytic inhibition assay).

Offspring: Blood samples collected from offspring at different times post-parturition (at 3 day, 2 week and 1month) for detection of maternal antibody. Collected serum samples from offspring were undergone for antitoxin units determination values using (mouse serum neutralization test, ELISA and haemolytic inhibition assay). 
Mouse serum neutralization test, was carried according European Pharmacopeia, 2001 after the determination of the mouse test dose of the used toxin.

Hemolytic inhibition assay, was carried according (Norris and Ribbons, 1971) after the determination the hemolytic test dose of the used toxin.

$$
\begin{aligned}
& \mathrm{b}_{\mathrm{WPLL}}=\left[\mathrm{n}(\Sigma \mathrm{xy})-\left(\sum \mathrm{x}\right)\left(\sum \mathrm{y}\right)\right]^{\mathrm{R}}+[\mathrm{n}(\Sigma \\
& \left.x y)-\left(\sum x\right)(\Sigma y)\right]^{\mathrm{S}} \\
& \left.\left[\mathrm{n}\left(\Sigma \mathrm{x}^{2}\right)-\Sigma \mathrm{x}^{2}\right)\right]^{\mathrm{R}+}\left[\mathrm{n}\left(\Sigma \mathrm{x}^{2}\right)-\left(\Sigma \mathrm{x}^{2}\right)\right]^{\mathrm{S}} \\
& \mathrm{D}=\mathrm{X}_{\mathrm{S}}-\mathrm{X}_{\mathrm{R}}-\left(\mathrm{Y}_{\mathrm{S}}-\underline{\mathrm{Y}}_{\mathrm{R}} \underline{\mathrm{D}}\right) \\
& \mathrm{U}_{\mathrm{S}}=\mathrm{U}_{\mathrm{R}}(\mathrm{Df}){ }^{\mathrm{D}} \\
& b_{\text {WPLL }}
\end{aligned}
$$

$G$ Graph of $Y=\alpha+B x$ is a straight line. That is all pairs of values of $X$ and $Y$ that satisfy an equation of the form $Y=\alpha+B x$ constitute points that fall on a straight line. The values of $(\alpha)$ and $(\beta)$ are usually estimated from observed data, and once they have been determined can be calculated the unknown value of $X$ when known the corresponding value of $Y$. A linear curve was done for relation between optical density obtained by ELISA and known samples previously measured antibody titer_by serum neutralization test, then when obtained the values $(\alpha, \beta)$ in the
Enzyme Linked Immunosorbent Assay (ELISA), was carried out according to (Walls 1977 and Wood 1991) for measuring of antibodies against Clostridium perfringens alpha toxin. The results were calculated according to the formula described by (Grabowska et al., 2002) by used of weighted parallel line model ( $\left.b_{\mathrm{WPLL}}\right)$ Linear Regression equation equation the unknown samples was calculated in the equation and shown the results of antibody titers in serum samples.

\section{Results and Discussion}

Rabbit industry and production have been developed and expanded all over the world to fill the gap between available and required animal protein for human being. Great attention is directed to the diseases causing economic losses to this industry from time to time (Finzi and Amici, 1991).

Enteritis in rabbit mainly after weaning is the major cause of economic commercial rabbitaries as it induces sudden death and high mortalities.

Enterotoxaemia due to $\boldsymbol{C}$. perfringens type $\mathrm{A}$ is widely

distributed all over the world causing severe losses and hinder animal production (Faried et al, 1993).

Vaccination against enterotoxaemia in rabbits was successfully used in many rabbit farms resulting in control of the disease in vaccinated farms, and it is very important for maternal immunity to the offspring 
where the antibodies were acquired by offspring from absorption of colostral antibodies. Maternal antibodies prevent immunizing of offspring after birth (Diab et al, 2003).

In order to enhance the immunogenic effect of the prepared vaccine and detect the best time for revaccination of dam's and vaccination of offspring , experiments were carried out for detection of the maternal antibodies in dams in different periods and times [from the first period of breeding then pregnancy till parturition (after $48 \mathrm{~h}, 2$ weeks and 1month)].Although detection the effect of the maternal immunization in offspring at different ages (4 days, 2weeks and 1month) for reaching the highest level of immune response against the disease.

Assays for measurement of antibody responses in serum samples using immunoassays are important diagnostic and epidemiological tools for a variety of purposes (Grabowska et al, 2002). ELISA assay for measurement of antibody titer in serum samples are important for vaccine titration instead of serum neutralization test in mice. Many studies have described a comparison of antibody units from the results obtained from ELISA (Reizenstein et al, 1995; Grabowska et al, 2002) . Serum neutralization test (SNT) is sensitive and reliable, it is slow (2-
3 days), relatively expensive and requires the usage of large numbers of mice (Makhareta et al, 1998).

Many studies have described comparisons of different methods for calculating antibody units from the results obtained by ELISA (Reizenstein et al, 1995) and different mathematical models for construction standard or calibration curves (Lagergard et al, 1988). So in this study obtained standard curve was calculated by Linear Regression method according to (Freund, 2001) which was useful and important not only because many relationships were actually of this form, but also because they often provide close approximations to relationships that would otherwise be difficult to described in mathematical terms.

The term linear equation arises from the fact that the graph of $Y=\alpha+\beta$ $X$ is a straight line. That is all pairs of values of $X$ and $Y$ that satisfy an equation of the form $\mathrm{Y}=\alpha+\beta \mathrm{X}$ constitute points that fall on a straight line. The values of $\alpha$ and $\beta$ are usually estimated from observed data, and once they have been determined can be calculated the unknown value of $X$ when known the corresponding value of Y $(\boldsymbol{E} \boldsymbol{l}$ Helw et al, 2012). These results of Table(1) and Figure (1) illustrated that when values of $\mathrm{X}(3 \mathrm{IU}, 1.5 \mathrm{IU}$ and $0.5 \mathrm{IU}$ ) by using SNT test, the values of $\mathrm{Y}(0.337,0.1065$ and 0.0945 O.D) in ELISA test for serum samples of rabbits. 
Although, there was another developed assays for measurement of antibody responses in serum samples as Haemolytic inhibition assay which is the lowest amount of toxin which cause haemolysis to the sheep RBCs. A wide range of RBCs of sheep, human, horses, cows, buffaloes, chickens could be haemolysed by $\boldsymbol{C}$. perfringens toxins (Mona, 1999). The red cells from different species varied in their susceptibility to the haemagglutinin of $\boldsymbol{C}$. perfringens. The differences in the sensitivity of different types of red cells to lysis by $\boldsymbol{C}$. perfringens haemolysins may be due to differences in the arrangement or number of receptor sites required to be saturated by haemolysin molecules before cell rupture occurs (Ramachandran, 1969).

The results obtained in table (2) and Figure (2) show the antitoxin titer against alpha toxin in sera of rabbits vaccinated with enterotoxaemia vaccine at breeding period gave high titer by SNT(1 IU/ ml), Haemolytic inhibition assay(3 IU) and ELISA test(1.63 IU) revealed that the results at this period for the three tests were nearly the same to each other.

At pregnancy period, the serum antibodies are lower during pregnancy in the rabbit so the protection against the disease was declined, so dam's must given a booster dose from the prepared vaccine to increase the immunity and although increase the maternal antibodies which transfer to the offspring. The results obtained in table (3) and Figure (3) show the antitoxin titer against alpha toxin in sera of rabbits vaccinated with Enterotoxaemia vaccine during pregnancy period by SNT(3 IU/ml), Haemolytic inhibition assay(7 IU) and ELISA test(3.74 IU) revealed that the results at this period for the three tests were nearly the same to each other.

In this study, parturition period were classified into three times (after 48 hours for detection of maternal antibodies, 2 weeks and 1 month for detection of the level of antibodies during lactation to determine the best time for revaccination). Table (4) and Figure (4) showed that the antitoxin titer against alpha toxin in sera of rabbit after parturition period by SNT gave after $48 \mathrm{~h}(2 \mathrm{IU} / \mathrm{ml})$, at 2 week $(1.5 \mathrm{IU} / \mathrm{ml})$ and 1 month(1IU/ml), Haemolytic inhibition assay gave after $48 \mathrm{~h}$ (5 IU),at 2weeks (3IU) and at 1 month( 2IU) and ELISA test gave after $48 \mathrm{~h}$ (2.06 IU), at 2weeks (1.7 IU) and at 1 month(1.39 IU). The results in the three tests gave high titer which decrease after 2 weeks but in the protective level so the dams must revaccinate after 1 month from parturition and enter in another pregnancy.

In Dams, The results showed variations of the immune response at different period (at breeding $1 \mathrm{IU} / \mathrm{ml}$, during pregnancy $3 \mathrm{IU} / \mathrm{ml}$ and after parturition at different 
times (1-2 IU/ml) but all within the protective level $(0.5-4 \mathrm{IU} / \mathrm{ml})$, the dam's during pregnancy gave the highest antitoxin titer than breeding period and parturition as it given a boaster dose to enhance the immunity and also increase antibody titer to offspring.

These results were agreed with (Barbara et al, 1985) Who stated that serum concentrations of $\mathrm{IgG}$ and specific antibody in nursing vaccinated rabbit dams remained fairly constant during the first 2 weeks of lactation at the same time that large amounts were being excreted in the milk so that the hyperimmunized dams fed for several periods during pregnancy or prior to and during lactation, both milk and serum antibody increased, but again the ratio remained fairly constant during lactation. Although serum $\operatorname{IgG}$ is lower during pregnancy in the rabbit (Peri et al, 1982), after parturition there must be a rapid increase in $\mathrm{IgG}$ production, including specific antibody, and probably increases in other immunoglobulin's as well, to compensate for the loss into milk.

Transmission of immunoglobulins between rabbit dam and kit were discussed by some to been entirely in utero through the yolk sac splanchnopleur (Brambell et al, 1949; Kleinman et al, 1983). (Adler \& Adler, 1982) demonstrated considerable uptake of foreign Ig allotype from milk in rabbits. Experiments on immunized dams detected the presence of antibodies in the serum of rabbit kits born to unimmunized dams. This suggested that the presence of specific antibodies in serum of kits nursed by an immunized dam (Peri and Rothberg, 1981) might relate to specific antibody or other factors absorbed from the milk. There were many studies confirms maternal IgG transmission through milk into the circulation of nursing kits.

The results of table(5) and Figure(5)

illustrated that when values of $X$ (2 IU, 1.5 IU and 0.5 IU)in SNT test the values of $\mathrm{Y}(0.209,0.155$ and0.0945 O.D)in ELISA test for serum samples of rabbits offspring. In this study, offspring classified according to age into three parts (after 4 days, 2 weeks and 1 month) as shown in table (6) and Figure (6) the antitoxin titer against alpha toxin in sera of offspring measured by SNT gave after 4 days (1.5 IU $/ \mathrm{ml}), 2$ weeks(1 IU/ml) and 1 month $(0.5 \mathrm{IU} / \mathrm{ml})$, Haemolytic inhibition assay gave after 4 days (4 IU), 2 weeks(2 IU) and 1 month(1 IU) and ELISA gave after 4 days (1.52 IU), 2 weeks(1.38IU) and 1 month(1.17 IU).The results revealed that there was specific antibodies against alpha toxin in sera of kits which indicated that the antibodies transfer passively from dam's to offspring (kits). The antitoxin titer decline after 1month so the kits must be vaccinated after weaned (46 week).

These results agreed with (ElSehemy et al, 2004) who said that active immunity in older animals 
conferred by immunization with specific vaccine was the only protective measure, and passive immunity to the newborn was taken via colostrums and confirmed that the antitoxin titer against $C$. perfringens type $\mathrm{A}(0.5-4 \mathrm{IU} / \mathrm{ml})$, ( Barbara et al, 1985) who found that at birth, kits had IgG and specific antibodies concentrations approximately equal to their dams. Both fell rapidly after the first 1020 days and post-suckling on immunized dams beginning at various times after birth showed antibody uptake from birth through12 days of age., (Felipe et al, 2013) who concluded that the presence of $\alpha$ - antitoxin in litter's of immunized animals may be due to animal colostrums intake, which is a key step for the passive immunizations of newborn offspring. And ensuring that all of the animals had access to take colostrum immediately after birth, which was reflected in the homogeneous alpha antitoxin titers and the low coefficient of variation among different litters, (Wikler et al, 1980) concluded that $\mathrm{s}$ female rabbits actively produced specific antibodies crossed with naïve males, significant offsprings $(40 \%)$ produced antibodies so maternal idiotypes have therefore strong immunoregulatory properties (Taher, 2006).

Finally, enterotoxaemia and bloat vaccine in rabbit gave antitoxin titer which give good protection against the disease at adult rabbit for 5 month ,so rabbit could be vaccinated after 5 month from primary vaccination, also revaccinate the Dam's at every pregnancy and after parturition periods to achieve high antitoxin titer to transport to newborn via colostrums and offspring could be vaccinated at first time after weaning (4-6 week) as a result of decrease in maternal immunity and increase mortalities in the weaned rabbit due to enteritis.

Table (1): Standard curve for reference serum samples of rabbit measured by ELISA.

\begin{tabular}{|c|c|}
\hline $\begin{array}{c}\mathrm{X} \\
\text { International Units measured by SNT }\end{array}$ & $\begin{array}{c}\text { Y } \\
\text { O.D at 490nm }\end{array}$ \\
\hline $3 I \mathrm{IU}$ & 0.337 \\
\hline $1.5 \mathrm{IU}$ & 0.1065 \\
\hline $0.5 \mathrm{IU}$ & 0.0945 \\
\hline \multicolumn{2}{|c|}{$\begin{array}{l}\text { SNT (Serum Neutralization Test). } \\
\text { O. D. (Optical Density) } \\
Y=\alpha+\beta \text { X }\end{array}$} \\
\hline$\alpha=(0.0095) \quad \beta=(0$ & $0168)$ \\
\hline
\end{tabular}




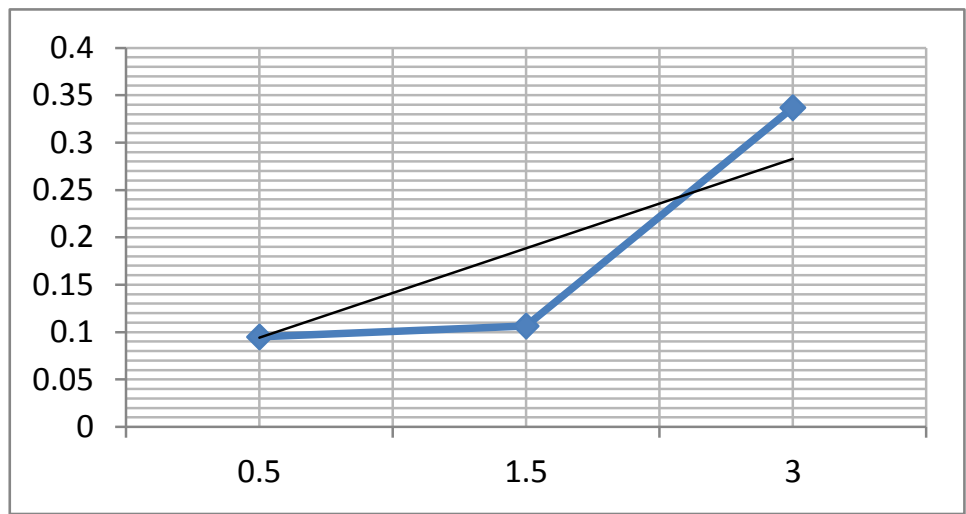

Figure (1): Standard curve for reference serum samples of rabbit measured by ELISA.

Table (2):Antitoxin titer against alpha toxin in sera of rabbit vaccinated with enterotoxaemia vaccine at breeding period by SNT, Haemolytic inhibition assay and ELISA test.

\begin{tabular}{|l|c|}
\hline \multicolumn{1}{|c|}{ Tests } & $\begin{array}{c}\text { Antitoxin titer against alpha toxin } \\
\text { in sera of rabbit at breeding period }\end{array}$ \\
\hline SNT & $1 \quad \mathrm{IU} / \mathrm{ml}$ \\
\hline Haemolytic inhibition assay & $3 \mathrm{IU}$ \\
\hline ELISA TEST & $1.63 \mathrm{IU}$ \\
\hline
\end{tabular}

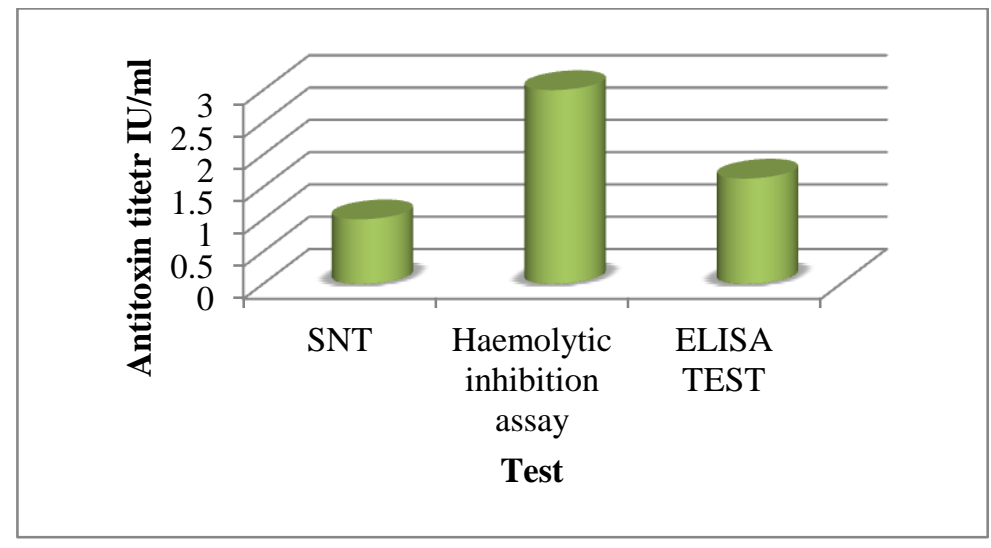

Figure (2): Antitoxin titer against alpha toxin in sera of rabbit at breeding period by SNT, haemolytic inhibition assay and ELISA test. 
Table(3):Antitoxin titer against alpha toxin in sera of rabbit during pregnancy period by SNT, haemolytic inhibition assay and ELISA test.

\begin{tabular}{|c|c|}
\hline Tests & $\begin{array}{l}\text { Antitoxin titer against alpha toxin in } \\
\text { sera of rabbit during pregnancy period }\end{array}$ \\
\hline SNT & $3 \mathrm{IU} / \mathrm{ml}$ \\
\hline Haemolytic inhibition assay & IU \\
\hline ELISA TEST & 3.74IU \\
\hline
\end{tabular}

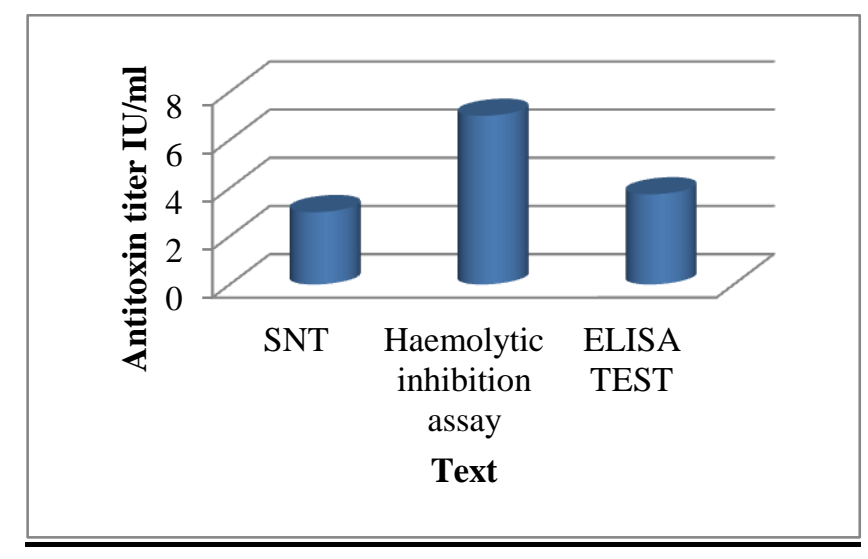

Figure (3): Antitoxin titer against alpha toxin in sera of rabbit during pregnancy period by SNT, haemolytic inhibition assay and ELISA test.

Table(4): Antitoxin titer against alpha toxin in sera of rabbit after parturition period by SNT, haemolytic inhibition assay and ELISA test.

\begin{tabular}{|l|c|c|c|}
\hline \multirow{2}{*}{ Tests } & \multicolumn{3}{c|}{ After parturition } \\
\cline { 2 - 4 } & 48hour & 2week & 1month \\
\hline SNT & 2 & 1.5 & 1 \\
\hline Haemolytic inhibition assays & 5 & 3 & 2 \\
\hline ELISA TEST & 2.06 & 1.75 & 1.39 \\
\hline
\end{tabular}




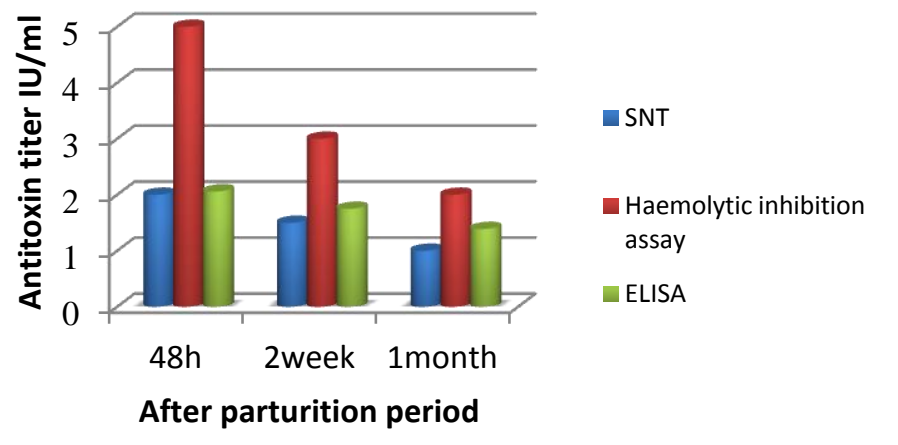

Figure (4): Antitoxin titer against alpha toxin in sera of rabbit after parturition period by SNT, haemolytic inhibition assay and ELISA test.

Table (5): Standard curve for reference serum samples of rabbit measured by ELISA.

\begin{tabular}{|c|c|}
\hline $\begin{array}{c}\mathbf{X} \\
\text { International Units measured by SNT }\end{array}$ & $\begin{array}{c}\mathbf{Y} \\
\text { O.D at 490nm }\end{array}$ \\
\hline 2 IU & 0.209 \\
\hline $1.5 \mathrm{IU}$ & 0.155 \\
\hline $0.5 \mathrm{IU}$ & 0.0945 \\
\hline
\end{tabular}

$$
\begin{gathered}
Y=\alpha+\beta X \\
\alpha=(0.054) \quad \beta=(0.074)
\end{gathered}
$$

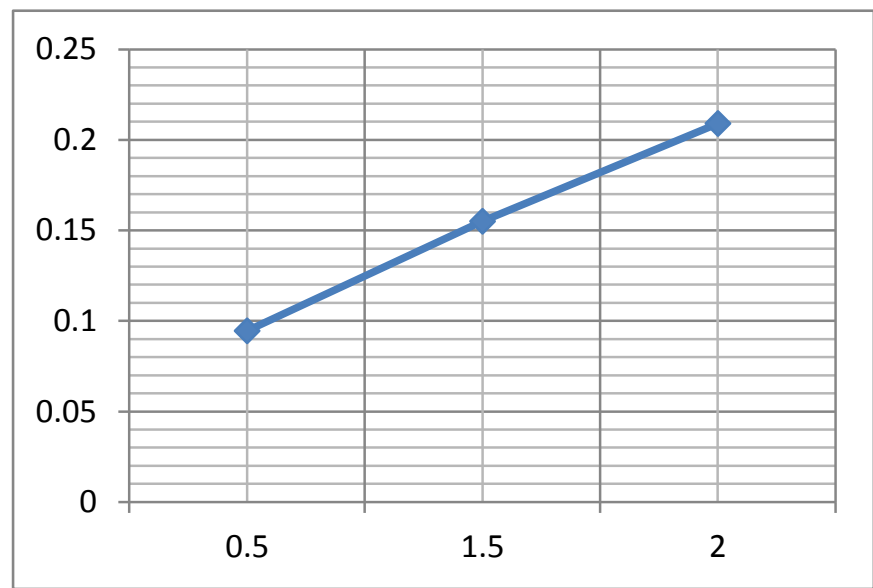

Figure (5): Standard curve for reference serum samples of rabbit measured by ELISA. 
Table(6): Antitoxin titer against alpha toxin in sera of offspring measured by SNT, haemolytic inhibition assay and ELISA.

\begin{tabular}{|c|c|c|c|}
\hline \multirow{2}{*}{ Time } & \multicolumn{3}{|c|}{ TESTS } \\
\cline { 2 - 4 } & SNT & HI & ELISA \\
\hline After4 days & 1.5 & 4 & 1.52 \\
\hline 2 week & 1 & 2 & 1.38 \\
\hline 1 month & 0.5 & 1 & 1.17 \\
\hline
\end{tabular}

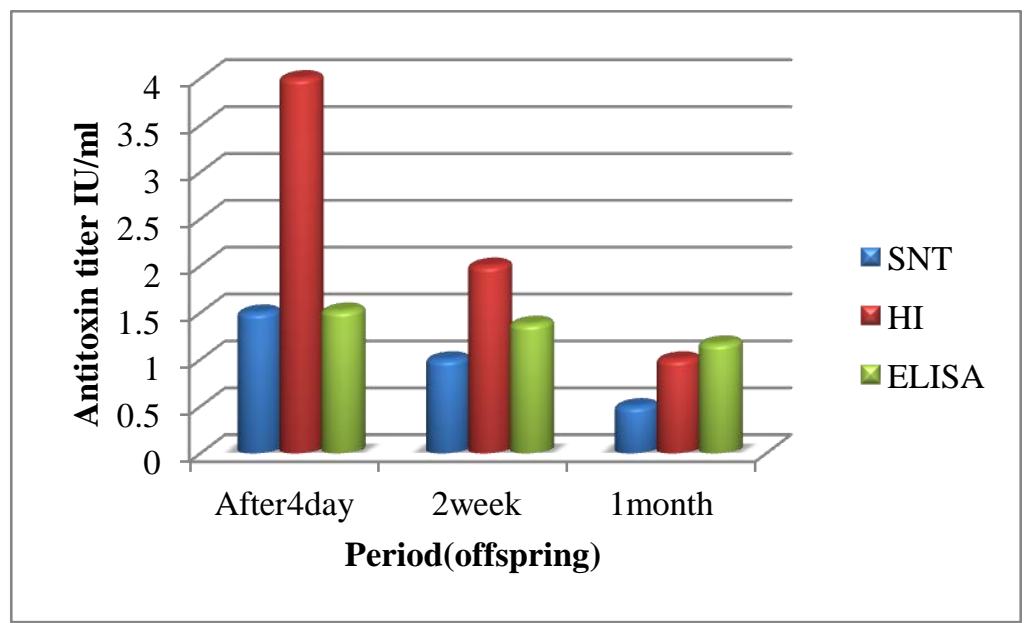

Figure (6): Antitoxin titer against alpha toxin in sera of offspring measured by SNT, haemolytic inhibition assay and ELISA.

It was concluded from the results that pregnant dams should be booster by one dose of vaccine to achieve high titer of antibodies and consequently give passive antibodies to offspring for one month. First vaccination for offspring after one month old. 


\section{References}

Adler, F.L. \& Adler, L.T. (1982):

Consequences of prenatal exposure to maternal. Ann. N. Y. Acad. Sci. 392, 266.

Barbara A. Peri and R. M. Rothberg(1985): Transmission of maternal antibody prenatally and from milk into serum of neonatal rabbits. Immunology 1986( 57) : 4953.

Brambell F.W.R., Hemmings W.A., Henderson M., Parry H.J. \&Rowlands W.T. (1949) : The route of antibodies passing from thematernal to the foetal circulation in rabbits. Proc. Roy. Soc. B. 136,131 .

Diab, R. A.; El-Sehemy, M. M.; Nadia, M. E.; Fatheia Shafie and Hussein, A. Z. (2003): Enterotoxaemia in rabbits and trials for preparing vaccine from the isolated strains. Journal of Veterinary Medical Association, 63(2):59-64.

Djurickovic, S. M. ; Dworak, J.E and Wickham, Kl (1975): Antitoxin titer in colostrum and milk after vaccination of sows with C.perfringens type c toxoid vaccine.Vet. Med. Small Anim. Clim. 283-285.

El- Helw, H. A.; Elham, F. EL Sergany; Taha, M. M.; Abdella, Y. A.; El - Sehemy, M. M. (2012): Comparison of ELISA with traditional methods used for evaluation of blackleg and gas gangrene vaccine. Nature and Science 10(11):137-144.
El-Sehemy, M. M.; Diab, R.A.; Hussien, A.Z.; Fathia Shafie and Roukia M. Osman (2004): "Immunological studies on rabbit enterotoxaemia vaccine". $6^{\text {th }}$ Sci. Conf., Egypt. Vet. Poult. Assoc., 2527.

Eurpean Pharmacopia(2001): $1.4^{\text {th }}$ edition,Council of Europe,67075, Strabourg Cedex France.

Faried, A. H.; Dorya Sharaf; Ebied , M. H. and Alaa, A. (1993): "Studies on enterotoxaemia in goats in Egypt" Benha Vet. Med. J.; 4(1): $120-129$.

Felipe M. Salvarania, Fabricio R. Conceicao , Carlos E.P. Cunha, Gustavo M.S.G. Moreira, Prhiscylla S. Pires, Rodrigo O.S. Silva, Guilherme G. Alvesa, Francisco and C.F. Lobato (2013): Vaccination with recombinant Clostridium perfringens toxoids $\alpha$ and $\beta$ promotes elevated antepartum and passive humoral immunity in swine. Vaccine, Jvac (14430): (4).

Finzi,A. and Amici,A. ( 1991): Traditional and alternative rabbit breeding systems for developing countries. Rivista di Agriculture Subtropical e Tropical, 6(1):103125.

Freund, J. E. (2001): Modern Elementary Statistics. $10^{\text {th }}$ Ed., Prentice Hall.

Grabowska, K.; Wang, X.; Jacobsson, A. and Dillner, J. (2002): Evaluation of cost-precision rations of different strategies for ELISA measurement of serum antibody levels. J. Immunol. Methods 271:1-15. 
Hara-Kudo, Y.; Morishita, Y.; Nagaoka, Y.; Kasuga, F. and Kumagai, S.(1996): Incidence of diarrhea with antibiotics and the increase of Clostridia in rabbits. Journal of Veterinary Medical Science.;58(12):1181-5.

Itodo, (1991): Association of C.perfringens type D epsilon toxin with sudden death of sheep in and around Vom, Nigeria. Isr. J. Vet. Med., 46:53-57.

Kleinman R.E., Harmatz P.R., Jacobson L.A., Udall J.N.,

BlockK.J. \& Walker W.A. (1983): Passive transplacental immunization: influence on the detection of enteric antigen in the systemic circulation. Pediatr. Res. 17, 449.

Lagergard, T., Trollfors, B., Claesson, B. A., Schneerson, R. and Robbins, J. B. (1988):Comparison between radioimmunoassay and direct and indirect enzyme - linked immunosorbent assays for determination of antibodies against Haemophilus influenza type b capsular polysaccharide.

J. Clin . Microbial, 26, 2554 - 2557. Lelkes, L.( 1987): A review of rabbit enteric disease a new perspective. J. Appl. Rabbit. Res.,10:55-61.

Lepas ， F.; Cmndrt, P.; Rochambeaude, H. and Thebault, R.G. (1977):

The rabbit husbandry, health and production (new revised version). FAO, Animal Production and Health Series, No.21.

Lovland, A.; Kaldhusdal, M.; Redhead, K.; Skjerve, E. and
Lillehaug, A. (2004):Maternal vaccination against subclinical nercrotic enteritis in broilers. Avian Pathol., 33(1):83-92.

Makhareta, M. A. M.; Hammam, H. M.; Fathia Shafei and Hussein, A. Z. (1998): A comparison between mice neutralization test and Enzyme Linked Immunosorbent Assay (ELISA) in detection of Clostridium perfringens types $\mathrm{B}$ and $\mathrm{D}$ antitoxins in sera of immune rabbits. J. Egypt. Vet. Med. Ass. 58, No. 1:1 $-12$.

Mona, M.M.(1999): Some studies on Clostridium perfringens toxins.

Ph.D. Thesis (Microbiology), Faculty of Veterinary Medicine Alexandria University.

Norris. J.R. and D.W. Ribbons (1971): "Methods in Microbiology". Academic press. London and New York volume 5A.

Peri, B.A. \& Rothberg, R.M. (1981): Specific suppression of antibodyproduction in young rabbit kits after maternal ingestion of bovine serum albumin. J. Immunol. 127, 2520.

Peri, B.A.; Theodore, C.M.; Losonsky, G.A.; Fishaut, J.M.; Rothberg, R.M. and Ogra P.L. (1982): Antibody content of rabbit milk and serum following inhalation or ingestion of respiratory synclinal virus and bovine serum albumin.

Ramachandran . S (1969): Haemolytic activities of $\boldsymbol{C}$. chauvoei.

Ind. Vet. Res. Inst., 48:745- 768.

Reizenstein,E.; Hallander, H. O.; Blackwelder, W. C.;Kuhn, I.; 
Ljungman, M., and Mollby, R.( 1995): Comparison of five calculation modes for antibody ELISA producers using pertussis serology as a model. J. Immunol. Methods 183:279-290.

Scharmann ,W. and Wolff, D. (1985): Occurrence and prevention of Tyzzer's disease in rabbit colony. The contribution of laboratory animal science to the welfare of man and animal, $8^{\text {th }}$ ICLAS/CALAS symposium, Vancouver,53-57. Sharma, J.M. (1999): Introduction of poultry vaccines and immunity. Adv. Vet. Med., 41:481-494.

Smith, L.D and Hodeman, L.V. (1968): The pathogenic anaerobic bacteria.

Charles Thomas publisher, U.S.A. Is ed. P 201-255.

Szemeredi ,G .; Palfi, and Gaco, I.(1983): Etiology of diarrhea in rabbits at weaning . Magyar Allatrovosok Lapja, 83(5):280-283.

Taher, M. M. (2006): Further bacteriological and immunological studies on

Clostridial microorganisms in poultry.

Ph.D. Thesis (Microbiology), Faculty of Veterinary Medicine cairo University.

Walls, K.W. (1977): Procedure guide for ELISA micro titration test center for disease control, Atlanta, Georgia, U.S. public Health service, Department of Health, Education and Welfare.

Wikler,C. Demeur, G. Dewasme and J. Urbain (1980): Immunoregulatory role of maternal idiotypes. J. Exp. Med (152):1024 1035.

Woods, K.R. (1991):An alternative to the toxin neutralization assay in mice for the potency testing of the Clostridium tetani, Clostridium septicum, Clostridium novyi type $B$, and Clostridium perfringens type $D$ epsilon components of multivalent sheep vaccines. Biological 19(4):281-286.

$$
\begin{aligned}
& \text { كثف المناعة الأمية للقاح التسمم المعوي ونفاخ الأرانب الكلوستريدي في مصل الأبل الأبل التوان }
\end{aligned}
$$

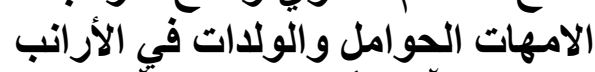

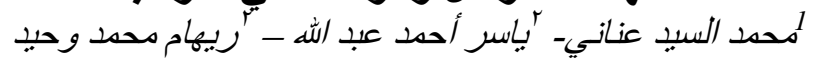

$$
\begin{aligned}
& 1 \text { ا كلية الطب البيطري -جامعة قناة السويس السيس }
\end{aligned}
$$

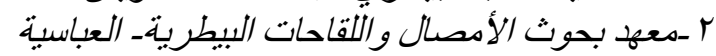

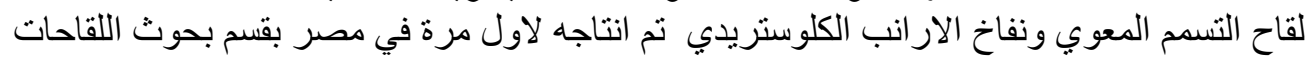

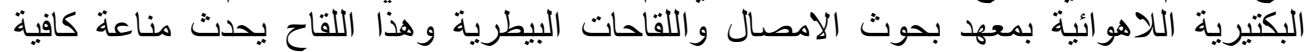

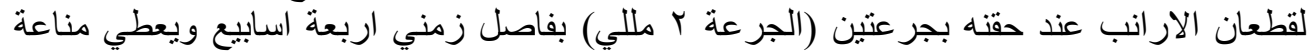

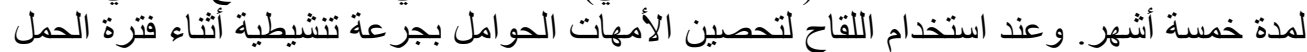

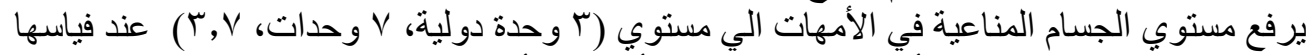

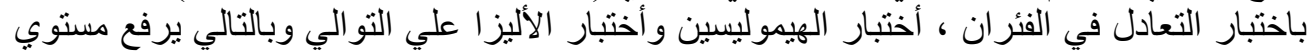

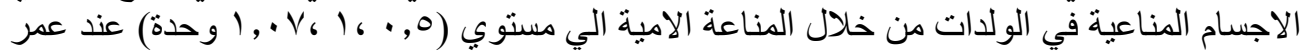

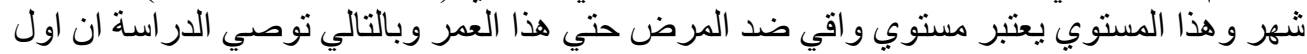
تحصبين للولدات يتم عند عمر شهر. 